\title{
A critical review of measures to reduce radioactive doses from drinking water and consumption of freshwater foodstuffs.
}

\author{
J.T. Smith ${ }^{1 *}$, O.V. Voitsekhovitch ${ }^{2}$, L. Håkanson ${ }^{3}$, J. Hilton ${ }^{1}$.
}

1. Institute of Freshwater Ecology, East Stoke, Wareham, Dorset, BH20 6BB, UK.

2. Ukrainian Hydrometeorological Institute, Nauka Ave. 37, Kiev 252028, Ukraine.

3. Institute of Earth Sciences, University of Uppsala, Norbyvägen 18-b, 75236

Uppsala, Sweden.

*Corresponding author, Fax: + 44 (0)1929 462180,E-mail: j.t.smith@ife.ac.uk.

Running head: Freshwater countermeasures.

Keywords: Countermeasures, water, fish, rivers, Chernobyl.

Published in Journal of Environmental Radioactivity:

J.T Smith, O.V. Voitsekhovitch, L. Håkanson, J. Hilton (2001) A critical review of measures to reduce radioactive doses from drinking water and consumption of freshwater foodstuffs. J. Environmental Radioactivity, 56, 11-32. 


\begin{abstract}
Following a radioactive fallout, there are a number of possible intervention measures to reduce radioactive doses to the public via the surface water pathway. We have critically reviewed the options available to decision makers in the event of radioactive contamination of surface waters. We believe that the most effective and viable measures to reduce radioactivity in drinking water are those which operate at the water treatment and distribution stage. Intervention measures to reduce concentrations of radioactivity in rivers and reservoirs are expected to be much less viable and efficient at reducing doses via the drinking water pathway. Bans on consumption of freshwater fish can be effective, but there are few viable measures to reduce radioactivity in fish prior to the preparation stage. Lake liming and biomanipulation have been found to be ineffective for radiocaesium, though addition of potassium to lakewaters appears promising in some situations. Lake liming may be effective in reducing radiostrontium in fish, though this has not, to our knowledge, been tested. De-boning fish contaminated by strontium is probably the most effective food preparation measure, but salting and freezing can also reduce radiocaesium concentrations in fish. The provision of accurate information to the public is highlighted as a key element of countermeasure implementation.
\end{abstract}




\section{Introduction}

Following a radioactive fallout, there are a number of possible intervention measures to reduce radioactive doses to the public via the surface water pathway. Countermeasures may be grouped into two categories: those aimed at reducing doses from radioactivity in drinking water and those aimed at reducing doses from consumption of aquatic foodstuffs, principally freshwater fish. In the context of an atmospheric fallout of radioactivity to both terrestrial and aquatic systems, it has been shown (Voitsekhovitch, Nasvit, Los’y \& Berkovski, 1997; Stone, Smith, Jackson \& Ibbotson, 1997) that doses from terrestrial foodstuffs are in general more significant than doses from drinking water and aquatic foodstuffs. Measures to reduce doses via drinking water may, however, be required, particularly in the short-term (timescale, weeks) after a fallout when activity concentrations in surface waters are relatively high. Measures to reduce doses via freshwater foodstuffs may be required over longer timescales as a result of bioaccumulation of radioactivity through the aquatic food chain. In addition it was found (Voitsekhovitch et al., 1997) that after the Chernobyl accident the public perceived that the contamination of water supplies was a much greater problem than it actually was. Thus, measures to protect water supplies were, in part, used as a method of restoring public confidence. It is also noted that surface waters are important transporters of radioactivity from contaminated zones to populations in less contaminated areas. The use of water supplies for drinking and irrigation, in the long term after fallout, generally results in small individual doses, but may lead to significant collective doses.

The purpose of this paper is to critically review the options available to decision makers in the event of radioactive contamination of surface waters. The review primarily considers the requirement for countermeasures in the context of a large scale atmospheric release of radionuclides, though many of the countermeasures are applicable to direct discharges to surface waters. We primarily consider the effectiveness of countermeasures in terms of individual dose reduction. As discussed below, however, other (much less quantifiable) factors such as social acceptability may influence countermeasure implementation. The review is principally based on experience, in the former Soviet Union and Western Europe, of radioactive contamination from the Chernobyl accident. The conclusions drawn, however, are intended to be applicable to any large scale contamination of surface waters. We will consider intervention measures to reduce doses at the following stages of the aquatic dose pathway (Fig. 1):

- Drinking water distribution and treatment;

- Direct and secondary contamination of surface waters;

- Uptake by fish and aquatic foodstuffs from contaminated water;

- Preparation of fish prior to consumption. 
Summary of the contamination of aquatic systems following Chernobyl.

The River Pripyat flows through the most heavily contaminated regions around Chernobyl. Although smaller streams and rainwater collectors (supplying drinking water for rural populations) may have had higher activity concentrations of radionuclides for short periods after the accident, contamination of the Pripyat can be considered as a "worst case” of drinking water contamination to populated areas.

Initial radionuclide activity concentrations in the rivers surrounding Chernobyl have been summarised by Vakulovsky and Voitsekhovitch (1990) and by Voitsekhovitch and co-workers (Voitsekhovitch, Borsilov \& Konoplev, 1991). Table 1 shows measurements (Kryshev, 1995) of radionuclide activities in the Pripyat at Chernobyl on 1 May 1986, four days after the accident. These measurements are compared with Generalised Derived Limits (GDL's) for drinking water based on an effective dose limit of 1 mSv. $\mathrm{y}^{-1}$ (NRPB, 1996). The GDL is determined by calculating the mean activity concentration in drinking water which, assuming consumption by the critical group over a one year period, would lead to a dose of $1 \mathrm{mSv}$ (NRPB, 1996). It should be noted that GDL's are for a given radionuclide and dose pathway and hence do not here account for exposure from multiple pathways and radionuclides. They are only used here to give an indication of relative contamination levels. Temporary allowable levels of radionuclides in drinking water in Ukraine at different times after Chernobyl are shown in Table 2.

Most radionuclides in the Pripyat river rapidly declined to insignificant levels as a result of physical decay and incorporation in catchment soils during the weeks following the accident. ${ }^{131} \mathrm{I}$, however had a relatively high initial activity concentration (2100 Bq..$^{-1}$ ), and ${ }^{137} \mathrm{Cs}$ and ${ }^{90} \mathrm{Sr}$ have long half-lives and so require further consideration. Despite the very long half-lives of isotopes of $\mathrm{Pu}$, its low solubility meant that levels dropped rapidly after the accident from $0.4 \mathrm{~Bq} . \mathrm{l}^{-1}$ $\left({ }^{239,240} \mathrm{Pu}\right)$ in May 1986 to 0.0074 Bq..$^{-1}$ in August 1986 (Kryshev, 1995).

In the Kiev Reservoir (fed by the Pripyat), ${ }^{131}$ I, with an initial concentration of 500 Bq. $\mathrm{l}^{-1}$, declined with a half-life close to its physical decay of 8.1 days to $20 \mathrm{~Bq} . \mathrm{l}^{-1}$ an estimated 37 days after the accident (calculated from data in Kryshev, 1995). ${ }^{131} \mathrm{I}$ in the Kiev Reservoir gave a maximum estimated dose of around $1 \mathrm{mSv}$ to infants (the critical group) from drinking water. The decline in ${ }^{131}$ I activity in the Pripyat river at Chernobyl is likely to have been faster than in the Kiev Reservoir (since there is no storage in the river system) so, despite the higher initial activities, doses are likely to have been of a similar order.

The long-lived isotopes ${ }^{137} \mathrm{Cs}$ and ${ }^{90} \mathrm{Sr}$ presented a potential long-term problem of drinking water contamination. As a result of sorption to catchment soils, activity levels in the Pripyat dropped rapidly from $250 \mathrm{~Bq}^{-l^{-1}}$ on $01 / 05 / 86$ to $1.8 \mathrm{~Bq} . \mathrm{l}^{-1}$ in 1987 for ${ }^{137} \mathrm{Cs}$, and from $30 \mathrm{~Bq} . \mathrm{l}^{-1}$ on $01 / 05 / 96$ to $1.5 \mathrm{~Bq} \cdot \mathrm{l}^{-1}$ in 1987 for ${ }^{90} \mathrm{Sr}$ (Kryshev 1995, Vakulovsky, Nikitin, Chumichev, Katrich, Voitsekhovitch, Medinets et al., 1994). ${ }^{137} \mathrm{Cs}$ activities continued to decline at a slower rate to around $0.2 \mathrm{~Bq} . \mathrm{l}^{-1}$ in 1991, but ${ }^{90} \mathrm{Sr}$ levels remained at around $1 \mathrm{~Bq} \cdot \mathrm{l}^{-1}$. Temporary increases of ${ }^{90} \mathrm{Sr}$ concentration to around $10 \mathrm{~Bq} \cdot \mathrm{l}^{-1}$ were observed during annual spring flooding of the 
Pripyat flood plain (Vakulovsky et al., 1994). In the Kiev Reservoir, ${ }^{90} \mathrm{Sr}$ and ${ }^{137} \mathrm{Cs}$ average activity concentrations were below $1 \mathrm{~Bq}^{-1} \mathrm{l}^{-1}$ in 1987 and subsequent years.

The most highly contaminated water bodies in the Chernobyl affected areas are the Flood Plain Reservoirs within the $30 \mathrm{~km}$ emergency zone. ${ }^{137} \mathrm{Cs}$ levels in these reservoirs in 1991 were below its Generalised Derived Limit (GDL, the activity concentration potentially leading to an annual dose of $1 \mathrm{mSv}$ ) for drinking water in the UK (100 Bq. $\mathrm{l}^{-1}$ : NRPB, 1996), the highest being 74 Bq. $\mathrm{l}^{-1}$ in L. Glubokoye during 1991 (Vakulovsky et al., 1994). ${ }^{90} \mathrm{Sr}$ levels, however, in many cases still exceeded the GDL for drinking water in the UK (50 Bq.l ${ }^{-1}$ : NRPB, 1996) during 1991, being between 100 and 370 Bq..$^{-1}$ in 6 of 17 studied water bodies (Vakulovsky et al., 1994). It should be noted that recommended limits for drinking water in the Ukraine (Table 2) are lower than the UK Generalised Derived Limits quoted above, partly because they account for exposure from other pathways whereas the UK limit is here presented for a single exposure pathway.

Doses from ${ }^{137} \mathrm{Cs}$ and ${ }^{90} \mathrm{Sr}$ contamination of waterbodies in the countries of the former Soviet Union (FSU) are difficult to quantify. Doses from the freshwater pathway (including fish and irrigation water) to the people of Kiev were relatively low, being around $5-10 \%$ of doses via terrestrial foodstuffs (Konoplev, Comans, Hilton, Madruga, Bulgakov, Voitsekhovitch et al., 1996). As radioactivity (mainly ${ }^{90} \mathrm{Sr}$ ) was transferred to less contaminated areas in the lower reaches of the Dnieper cascade of reservoirs, the contribution to dose via freshwaters increased to $10-20 \%$. The critical group amongst the 30 million users of Dnieper water were commercial fishermen in the Kiev Reservoir who, in 1986, received a dose of $5 \mathrm{mSv}$ from ${ }^{137}$ Cs contamination of fish (Berkovski, Voitsekhovitch, Nasvit, Zhelesnyak \& Sansone, 1996). These commercial fishermen were estimated to consume up to $360 \mathrm{~kg}$ of fish per year, fish being the main component of their diet. For the population living around the Dnieper river-reservoir system, consumption estimates were much lower, being around 5-7 kg per year. These consumption estimates can be compared with critical group freshwater fish consumption estimates in the UK of ca. $20 \mathrm{~kg}$ per year (NRPB, 1996).

\section{${ }^{137} \mathrm{Cs}$ in freshwater fish}

During the years following the Chernobyl accident there have been numerous studies of the levels of contamination of freshwater fish by radiocaesium. Work has shown that, as a result of high radiocaesium concentration factors (CF's) $\left(10^{2}-10^{4} 1 . \mathrm{kg}^{-1}\right)$, fish have remained contaminated despite relatively low radiocaesium levels in water. In many cases activity concentrations have greatly exceeded the European Union intervention level for radiocaesium activity in fish of around $1000 \mathrm{~Bq} \cdot \mathrm{kg}^{-1}$ wet weight (w.w.).

The processes which determine the accumulation of radiocaesium in fish are complex, and lead to wide differences in contamination levels according to fish type, size and feeding patterns. The most important pathway of radiocaesium into fish is via intake of food, and the high concentration factors observed are a result of accumulation of radiocaesium through the food chain. In general, predatory fish such as pike and perch show higher concentration factors than herbivorous species (Hadderingh, van Aerssen, Ryabov, Koulikov \& Belova, 1997). The "size effect" of radiocaesium 
accumulation in fish most commonly results in an increasing contamination (per unit weight of fish) with increasing fish size (Elliott, Hilton, Rigg, Tullett, Swift \& Leonard, 1992; Hadderingh et al., 1997).

In the Chernobyl cooling pond ${ }^{137}$ Cs levels in carp, silver bream, perch and pike were of order $100 \mathrm{kBq} \cdot \mathrm{kg}^{-1}$ w.w. in 1986, declining to a few tens of $\mathrm{kBq}^{\mathrm{kg}}{ }^{-1}$ in 1990 (Kryshev and Ryabov, 1990; Kryshev, 1995), fish from the Cooling Pond were not consumed after the accident. In fish in the Kiev Reservoir activity concentrations in fish were in the range $0.6-1.6 \mathrm{kBq} \cdot \mathrm{kg}^{-1}$ wet weight (1987) and $0.2-0.8 \mathrm{kBq} \cdot \mathrm{kg}^{-1}$ w.w. (1990-1995) for adult non-predatory and 1 - $7 \mathrm{kBq} \cdot \mathrm{kg}^{-1}$ (1987) and 0.2-1.2 kBq.kg-1 (1990-1995) for predatory fish species. In lakes in the Bryansk region, approximately $400 \mathrm{~km}$ from Chernobyl, activities in a number of fish species varied within the range 0.215 -18.9 kBq. kg ${ }^{-1}$ w.w. during the period 1990-92 (Fleishman, Nikiforov, Saulus \& Komov, 1994; Sansone and Voitsekhovitch, 1996). In Scandanavian lakes, Brittain and co-workers (Brittain, Storruste \& Larsen, 1991) found that activity concentrations in brown trout were in the range $2-13 \mathrm{kBq} \cdot \mathrm{kg}^{-1}$ shortly after the accident, declining to $0.5-5 \mathrm{kBq} \cdot \mathrm{kg}^{-1}$ in 1989. In some Alpine lakes in Germany, levels in pike were up to $5 \mathrm{kBq} \cdot \mathrm{kg}^{-1}$ shortly after the Chernobyl accident (Zibold, Förstner, Drissner, Klemt, Miller \& Walser, 1998). In Devoke Water in the English Lake District, perch and brown trout contained around $1 \mathrm{kBq} \cdot \mathrm{kg}^{-1}$ in 1988 declining slowly to a few hundreds of Bequerels per kg in 1993 (Camplin, Leonard, Tipple \& Duckett, 1989 and pers. comm.). Levels of radiocaesium in fish declined relatively rapidly between 1986 and 1989 with an ecological half-life of around 3 years (Brittain et al., 1991; Kryshev, 1995), but there is evidence to suggest (Fleishman et al., 1994) that between 1990 and 92 levels stabilised, so that rates of decline may decrease to close to the physical decay half-life of ${ }^{137} \mathrm{Cs}, 30.2$ years (Smith, Comans, Beresford, Wright, Howard \& Camplin, 2000a).

Since the European Union recommended intervention level of radiocaesium activity for consumption of fish is ca. $1 \mathrm{kBq} \cdot \mathrm{kg}^{-1}$ w.w., it is clear that the contamination of fish following the Chernobyl accident was a cause of concern in the short term (months) for less contaminated areas (for example, parts of the UK and Germany) and in the long term (years-decades) in the Chernobyl affected areas of Ukraine, Belarus and Russia and parts of Scandanavia.

In rural parts of the Chernobyl contaminated areas of the FSU during 1994-5, it was found that so-called "wild foods" (mushrooms, berries, freshwater fish, game animals) had radiocaesium contents which were around one order of magnitude higher than agricultural products (eg milk or meat). Prior to the Chernobyl accident, $17 \%$ of the population of the Bryansk region (one of the areas where fish were most highly contaminated by radiocaesium) consumed fish from local lakes (Balonov and Travnikova, 1990). Whole body monitoring of people living close to Lake Kozhanovskoe, Bryansk, showed (Strand, Howard \& Averin, 1996) that ${ }^{137}$ Cs intake by the population was strongly correlated with levels of consumption of freshwater fish.

In Western Europe, consumption of freshwater fish does not form an important part of the diet, but sports and commercial fisheries may be of economic importance in some areas. Though not necessarily dependent on the consumption of fish, angling is one of Europe's most popular leisure activities. Fallout from Chernobyl had little effect 
on fisheries in the UK, though anecdotal evidence suggests that it was a cause of (unfounded) concern amongst anglers in the more heavily contaminated areas such as the western part of Cumbria. In Norway, where fallout levels were up to one order of magnitude higher, consumption of freshwater fish declined by up to $50 \%$ in the more contaminated areas, and the sale of freshwater fish to the general public was prohibited in these areas (Brittain et al., 1991). These authors also reported that the sale of fishing licences in parts of Norway declined by 25\% after Chernobyl.

${ }^{131}$ I in freshwater fish.

Kryshev (1995) presents measurements of ${ }^{131} \mathrm{I}$ in fish in the Kiev Reservoir shortly after Chernobyl. The fish-water CF was around 10, and activities in fish muscle declined on a timescale similar to that of physical decay from around $6000 \mathrm{~Bq} \cdot \mathrm{kg}^{-1}$ on 01/05/86 to $50 \mathrm{~Bq} \cdot \mathrm{kg}^{-1}$ on 20/06/86. The GDL for ${ }^{131} \mathrm{I}$ in freshwater fish is 2000 Bq. $\mathrm{kg}^{-1}$ (NRPB, 1996), although the critical group intake on which this is based (20 $\mathrm{kg} . \mathrm{y}^{-1}$ ) is one order of magnitude lower that that quoted by Berkovski and coworkers (1996), based on studies of consumption by Ryabov (1992) for commercial fishermen in the Kiev Reservoir.

${ }^{90} \mathrm{Sr}$ in freshwater fish.

Relatively low fish-water CF's for ${ }^{90} \mathrm{Sr}\left(10-1001 . \mathrm{kg}^{-1}\right)$ meant that ${ }^{90} \mathrm{Sr}$ levels in fish were much lower than those of ${ }^{137} \mathrm{Cs}$. In the Chernobyl cooling pond, ${ }^{90} \mathrm{Sr}$ activities were around $2 \mathrm{kBq} \cdot \mathrm{kg}^{-1}$ in fish during 1986, compared with around $100 \mathrm{kBq} \cdot \mathrm{kg}^{-1}$ for ${ }^{137}$ Cs (Kryshev, 1995). None of the literature studied has suggested that postChernobyl ${ }^{90} \mathrm{Sr}$ levels in fish were significant in comparison with ${ }^{137} \mathrm{Cs}$.

\section{Review of aquatic countermeasures}

Potential aquatic countermeasures we have identified from the literature are outlined below. These countermeasures have been summarised in tabular format (on an EXCEL spreadsheet) in Voigt, Eged, Hilton, Howard, Kis, Nisbet et al. (2000).

Measures to reduce doses at the water supply and treatment stage.

Bans on drinking water consumption. Temporary bans on drinking water consumption and provision of alternative supplies may be required immediately after a fallout. Since radionuclide activity concentrations tend to decline rapidly (half-life, $T_{1 / 2}$, of decline of Cs and $\mathrm{Sr}$ in runoff water during this early period is typically 2 weeks and $\mathrm{T}_{1 / 2}$ of ${ }^{131} \mathrm{I}$ is 5-6 days, Smith, Kudelsky, Ryabov, Hadderingh, van der Perk \& Voitsekhovitch, 1999a), such bans are not likely to be in place for more than a few weeks after fallout except, possibly, in lakes of long water residence time.

Switching or blending of drinking water supplies. Switching to less contaminated supplies is an accepted and effective countermeasure to radioactive contamination of drinking water. If the water supply system is sufficiently integrated, supplies may rapidly be switched to groundwater sources, or less contaminated surface water sources. The effectiveness of this countermeasure is dependent on a rapid assessment of the extent of contamination of different water supplies. This countermeasure is discussed further in, 
for example, Tsarik (1993); Voitsekhovitch et al. (1997); Stone et al. (1997). A summary of the measures taken by the Ukrainian authorities to switch to alternative supplies from less contaminated rivers and from groundwater can be found in Voitsekhovitch (1998).

\section{Supplementary purification of drinking water in municipal water treatment plants.} A study has been carried out of the potential for removal of $\mathrm{Ru}, \mathrm{Co}$, I and $\mathrm{Cs}$ by conventional water treatment (Goosens, Delville, Genot, Halleux \& Masschelein, 1989). These workers found that removal efficiencies of Ru, Co, I and Cs were 73\%, 61\%, 17\% and 56\% respectively. The mechanism for removal was by attachment to and settling of solid particles during flocculation, as well as, for Cs, removal during sand filtration. In the Chernobyl context, standard water treatment would have had a limited effect on ${ }^{131} \mathrm{I}$ (17\% removal), the major short-term contaminant of drinking water. In the Dnieper Waterworks Station, activated charcoal and zeolite were added to water filtration systems. It was found that activiated charcoal was effective in removing ${ }^{131} \mathrm{I}$ and ${ }^{106} \mathrm{Ru}$, and zeolite was effective in removing ${ }^{137,134} \mathrm{Cs}$ and ${ }^{90} \mathrm{Sr}$ (Tsarik, 1993). These sorbents were found to be effective for the first three months, after which they became saturated and their efficiency declined (Tsarik, 1993; Voitsekhovitch, 1998).

Regulation of flow of contaminated water through reservoirs. After Chernobyl, surface gates on the Kiev Reservoir dam were opened. It was believed at the time that the surface water was relatively low in radionuclide content and that the release of water would allow room in the reservoir to contain runoff water which was believed to be highly contaminated. In fact, because of direct atmospheric deposition to the reservoir surface, surface waters in the reservoir were much more contaminated than deep waters. As noted by Voitsekhovitch et al. (1997) "A better approach to lowering the water level within the Kiev Reservoir would have been to open the bottom dam gates and close the surface gates. This would have reduced the levels of radioactivity in downstream drinking water in the first weeks after the accident”. Although this countermeasure was not efficiently implemented after Chernobyl, regulation of flow, given the correct information of contamination, could effectively reduce activity concentrations in drinking water, as it takes some time (days or more) for lakes and reservoirs to become fully mixed.

Measures to reduce direct and secondary contamination of surface waters.

Measures to reduce runoff of radionuclides in particulate form. Standard anti-soil erosion measures could be used to reduce runoff of radionuclides attached to eroded soil particles (see, for example, Schwab, Frevert, Edminster \& Barnes, 1966; Morgan, 1986). Typically, suspended solids concentrations in river and lake waters are $<50$ mg. $\mathrm{l}^{-1}$. In this case less than $50 \%$ of radiocaesium and less than $10 \%$ of radiostrontium and radioiodine are expected to be in the particulate phase, limiting the potential effectiveness of this countermeasure. It is also noted that the dissolved, rather than particulate, form of these radionuclides is important in determining activity concentrations in drinking water and freshwater biota.

Dredging of canal-bed traps to intercept suspended particles in contaminated rivers was carried out after Chernobyl (Voitsekhovitch, Kanivets \& Shereshevsky, 1988). These canal-bed traps were found to be highly inefficient for two reasons: (1) flow rates were too high to trap small suspended particles carrying much of the radioactivity; (2) a 
significant proportion of the activity (and most of the "available" activity) was in dissolved forms and thus would not have been intercepted by the sediment traps.

Reduction in runoff of radionuclides in dissolved form. Buffer strips adjacent to rivers can be used to trap eroded particles and encourage infiltration of overland flow to increase sorption of radionuclides to soil. Buffer strips have been used to reduce runoff of fertilisers and pesticides from agricultural land, but are untested for radionuclides. Removal of radioactivity from water by "filtering" through reed beds is also possible, though probably not feasible on a large scale. Zeolite containing dykes were constructed on smaller rivers and streams around Chernobyl in order to intercept dissolved radionuclides. These were found to be very ineffective: only $5-10 \%$ of the ${ }^{90} \mathrm{Sr}$ and ${ }^{137} \mathrm{Cs}$ in the small rivers and streams were adsorbed by these zeolite barriers (Voitsekhovitch et al., 1997; Voitsekhovitch, 1998). In addition, the rivers and streams on which they were placed were later found to contribute only a few percent to the total activity load in the Pripyat-Dnieper system.

Flood prevention measures. After Chernobyl, spring flooding of the highly contaminated Pripyat flood plain resulted in increases in ${ }^{90} \mathrm{Sr}$ activity concentrations in the River Pripyat from annual average activity concentrations of around $1 \mathrm{~Bq} \cdot \mathrm{l}^{-1}$ to a maximum of around $8 \mathrm{~Bq} . \mathrm{l}^{-1}$, the flood event covering an approximately 2 week period (Vakulovsky et al., 1994). The construction of a dyke around the most contaminated areas of the flood plain has proved effective in reducing ${ }^{90} \mathrm{Sr}$ loads during these flood events (Voitsekhovitch et al., 1997). Annual average ${ }^{90} \mathrm{Sr}$ activity concentration in Kiev Reservoir water, however, was below 1 Bq. ${ }^{-1}$ for all years from 1987 onwards. The radiological significance of the ${ }^{90} \mathrm{Sr}$ activity concentrations in Kiev Reservoir water, even during the short flood events, is therefore very low, though it has been argued that the averted collective dose to the large number of users of the river-reservoir system is significant.

Sedimenting out radionuclides from lakes and reservoirs. It is potentially possible to increase the sedimentation of radionuclides from lakes and reservoirs by introduction of strongly sorbing material, such as a zeolite or an (uncontaminated) mineral soil. This method has not to our knowledge been tested. Using a model for the removal of radiocaesium from lakes by settling of suspended particles (Smith, Comans \& Elder, 1999b), we have estimated the effect of increasing suspended particle concentration on the rate of removal of radiocaesium from lakes of different sizes (Table 3 and Fig. 2).

Note that we have assumed in this analysis that the distribution coefficient $\left(\mathrm{K}_{\mathrm{d}}=80,000\right.$ l.kg-1) of the sorbing material is the same as that typically observed for suspended particles in the lakewater. Potentially, specific caesium sorbing material could be more efficient, but this may be expensive. There are two problems with this method of reducing radiocaesium in lakes: (1) large, deep lakes would require large amounts of sorbent (Table 3); (2) secondary contamination of the lake by remobilisation of activity from the catchment and/or bottom sediments would require repeat applications in most systems. One should also note that in practice it would be difficult and expensive firstly to increase the concentration of suspended particulate matter by a factor of two in natural lakes/reservoirs and secondly also to maintain the higher concentrations since the net fall velocity of suspended particulate matter generally would be about 0.5 to 2 m.day $^{-1}$ (Håkanson, 1999). 
Bans on consumption of freshwater fish. Bans on consumption of freshwater fish have been applied in the restricted zones of Chernobyl (Ryabov, 1992). In some areas, selective bans on the more contaminated predatory fish have been applied. It is believed that bans are often ignored by fishermen. Bans on the sale of freshwater fish have been applied in some areas of Norway (Brittain et al., 1991). Use of farmed fish has been suggested by Smith, Kudelsky, Ryabov \& Hadderingh (2000c) as an alternative source of freshwater fish in areas affected by fishing bans. Farmed fish, fed with uncontaminated food, do not significantly accumulate radionuclides (Camplin et al., 1989; Smith et al., 2000c).

Lake liming. These measures were tested in 18 Swedish lakes (Håkanson and Andersson, 1992). Different types of lime were used: primary rock lime (PR) was used in 10 lakes, sedimentary rock lime in 6 lakes and so-called mixed lime (a lime also containing various trace elements and nutrients) in 2 lakes. The lime was spread over the lakes by different methods, such as helicopters, pontoon boats and dosers in the mouth of the tributaries. The amounts of lime supplied were as one or several applications, either on ice or directly into the water. As a result of the liming, the mean $\mathrm{pH}$ of the lakes increased from 6.0 to 6.7, and also other parameters which are directly linked to the addition of lime, for example, hardness and alkalinity, showed strongly increased long-term mean values. A certain decrease in the colour of the lakes was also noted. The results of the experiments showed that liming had no significant effect on uptake of ${ }^{137} \mathrm{Cs}$ in fish in comparison with control lakes. Although uptake of ${ }^{90} \mathrm{Sr}$ was not studied in these experiments, it is expected that increased Ca concentration in lakes may have an effect on ${ }^{90} \mathrm{Sr}$ concentration in fish. Experience of lake liming, in conjunction with artificial feeding of fish in the Ukraine has been summarised by Voitsekhovitch (1998).

Wetland liming. This was carried out in the catchment areas of 17 lakes, of which 8 were limed with primary rock lime, 7 with sedimentary lime and 2 with "mixed lime". The amount of lime added followed the recommendations by the Swedish Environmental Protection Agency, which implies 0.3 tonnes per hectare totally over the catchment area, 15 tonnes per hectare on wetlands where the wetlands make up $2 \%$ of the area, and 3 tonnes per hectare on wetlands where the wetlands make up $10 \%$ of the area (see Håkanson and Peters, 1995). The supply was done using helicopters and a single application. In theory, wetland liming has several advantages in comparison with lake liming:

- A considerably prolonged durability.

- A possible "liming shock" in the lake is avoided.

- Improved conditions for animals and plants in streams and rivers; reduced transport of several metals (e.g., Fe and $\mathrm{Al}$ ) into the lake from the catchment area.

Full-scale drainage area liming was done in two areas using dolomite. Since the dolomite is less soluble than ordinary limestone, the durability should be further prolonged.

Although the mean $\mathrm{pH}$ in the limed lakes increased from 6.0 to 6.7, and also other variables which are directly linked to the liming remedies (e.g. hardness and alkalinity) 
showed increased long-term mean values, no effect of the countemeasure was observed in ${ }^{137} \mathrm{Cs}$ activity concentrations in fish.

Addition of potassium to lakewaters. It is known that the concentration factor of radiocaesium in fish is inversely related to the potassium content of the surrounding water (for example, Fleishman, 1973; Blaylock, 1982; Smith, Kudelsky, Ryabov \& Hadderingh 2000b). After Chernobyl, potassium was added to 13 lakes in Sweden either as potash or as an additive in the mixed lime (Håkanson and Andersson, 1992). In most of the treated lakes, mean potassium concentrations were increased from less than 0.4 mg. $\mathrm{l}^{-1}$ to in excess of $0.8 \mathrm{mg} . \mathrm{l}^{-1}$. The results of the potash treatment were somewhat inconclusive, with a small reduction in activity concentrations in perch fry being observed during the two year experiment. It was found that in lakes with short water retention times it was difficult to maintain high levels of $\mathrm{K}^{+}$in the lake. In an experiment on Lake Svyatoe in Belarus, Smith \& coworkers (Smith et al., 2000c) added potassim chloride fertilizer onto the frozen lake surface. This resulted in an increase of the lakewater potassium concentration from $1 \mathrm{mg} . \mathrm{l}^{-1}$ to $10 \mathrm{mg} \cdot \mathrm{l}^{-1}$. Because of the long water residence time of this lake (it has no outflow), potassium concentration was still 7-8 mg. $\mathrm{l}^{-}$ ${ }^{1}$ two years after application. Results showed a $50 \%$ reduction in ${ }^{137} \mathrm{Cs}$ concentration in fish during the first year after the experiment (Smith et al., 2000c). The efficiency of this countermeasure, however, is reduced by the release of ${ }^{137} \mathrm{Cs}$ from sediments by competition with the increased $\left[\mathrm{K}^{+}\right]$. In L. Svyatoe ${ }^{137} \mathrm{Cs}$ in the water increased by a factor of 2-3 after the countermeasure application. Modelling (Smith et al. 2000c) showed that, in this lake, the countermeasure is effective, leading to a significantly (ca. $50 \%$ ) reduced ${ }^{137}$ Cs activity concentration in fish for a period of up to 10 years for a single application. It is likely, however that potassium treatment is only feasible in lakes with very long water residence times, allowing increased potassium concentrations to be maintained. Also, the increased ${ }^{137} \mathrm{Cs}$ in water is unlikely to be acceptable in lakes where water is abstracted for drinking.

Manipulation of the aquatic food web: intensive fishing and fertilization. Intensive fishing was carried out in 4 lakes in Sweden (Hakanson and Andersson, 1992) and as a complementary measure in a further 3 lakes. This resulted in a reduction of the fish population by about 5-10 kg per hectare. The species reduced were mainly pike, perch and roach. No effect of intensive fishing on ${ }^{137} \mathrm{Cs}$ concentrations in fish was observed. Fertilization was carried out in 2 Swedish lakes using "Osmocoat" (5\% P and 15\% N). The concentrations of total-P generally showed no change in the long-term mean value: it appears that the fertilization remedy was not conducted sufficiently effectively. No effect was observed on ${ }^{137}$ Cs activity concentrations in fish.

\section{Preparation of fish prior to consumption.}

Different methods of food preparation may affect the quantity of radionuclides in consumed food. Ryabov (1992) suggested bans on consumption of smoked and dried fish since these processes increase concentrations of radionuclides (per unit of weight consumed). Other preparation processes may reduce radioactivity in fish.

De-boning prior to consumption. Although radiocaesium is relatively evenly distributed throughout the fish, radiostrontium is strongly concentrated in the bony parts of fish, with approximately $50 \%$ or more of the radioactivity being found in the bones 
(Coughtrey and Thorne, 1983). An effective measure to reduce consumption of radiostrontium is to remove the bony parts of fish prior to cooking.

Salting fish. It has been known for a long time that salting may eliminate ${ }^{137} \mathrm{Cs}$ from meat. After 2 - 4 days immersion in concentrated salt solution, the ${ }^{137}$ Cs concentration in a 500g piece of meat is reduced by 60 - 70\% (Wallström and Håkanson, 1991). There are at least three severe drawbacks with this salting method.

1. The amount of vitamins (e.g. B6, B12) would decrease significantly with the time of exposure; after 2 - 4 days most of these vitamins would be lost.

2. The levels of $\mathrm{Na}$ (and $\mathrm{K}$ ) would increase and this would influence the taste of the meat; a large intake of $\mathrm{Na}$ and $\mathrm{K}$ may also give rise to negative health effects in man.

3. The colour and texture of the meat would change, and most people would probably agree that the grayer and harder meat obtained after 2-4 days in a salt solution would be less appetizing than normal, fresh meat.

Tests were carried out (Wallström and Håkanson, 1991) to try to speed up the salting procedure from 2 - 4 days to 2 - 4 hours. Different types of salts were tested, as well as different types of meat, and different forms and sizes of the meat. Two different approaches to speed up the salting procedure were also tested: rotating the meat in the salt solution (called centrifugation) or to rotate the salt solution around the meat (called rotation). Both rotation and centrifugation in salted water may reduce ${ }^{137} \mathrm{Cs}$ in meat (moose, deer and fish) by $60-70 \%$ in $2-3$ hours. The first round (of centrifugation or rotation) was most efficient in reducing ${ }^{137} \mathrm{Cs}$ : about $30-50 \%$ of the ${ }^{137} \mathrm{Cs}$ may be reduced in the first round (depending on the salt concentration and the type of meat), with about $10-15 \%$ reduction in subsequent rounds. There is no significant change in vitamin B6 if the treatment lasts for 2-3 hours. There is also no significant change in the texture of the meat, except an increase in the Na-concentration. The best results in terms of ${ }^{137} \mathrm{Cs}$ reduction were obtained for meat that had been frozen: frozen meat showed a 20 - $40 \%$ reduction in ${ }^{137}$ Cs compared to unfrozen.

The rotation and centrifugation procedure takes $2-3$ hours and it requires access to a household machine that could either centrifugate the meat (about 1000 rotation/min.) or rotate the salt solution. However, salting, speeded up by rotation, may be a practical method in areas with heavily contaminated meat, especially for larger kitchens (schools, military, restaurants, etc.). It may also be used in homes, because there may be people who, from primarily a psychological point of view, would like to feel that they are able to do something themselves to reduce their intake of radioactive caesium.

\section{Groundwater.}

To our knowledge, there have been no measures to protect groundwater supplies after an atmospheric deposition of radioactivity. Groundwater residence times are long enough that shorter lived radionuclides such as ${ }^{131} \mathrm{I}$ will have decayed long before they affect drinking water. Only very small amounts of radiostrontium and radiocaesium percolate from surface soils to groundwaters after atmospheric deposition. A study by Bugai and coworkers (Bugai, Waters, Dzhepo \& Skal'skij 
1996) showed that after Chernobyl, exposure to ${ }^{90} \mathrm{Sr}$ and ${ }^{137} \mathrm{Cs}$ via the groundwater pathway was insignificant in comparison with other pathways (food, external exposure). It is noted, however, that contamination of groundwater from buried radioactive waste could lead to significant doses in some situations.

\section{Irrigation water.}

There is little information available on the use of contaminated water for irrigation purposes. If the water originates from contaminated areas and is used to irrigate similarly contaminated soils, it will add little to the radioactivity in crops since activity levels in the irrigation water will be comparable to those in the in situ soil water. In areas where water originating in a contaminated area is used to irrigate much less contaminated soils, there is a potential problem. This latter scenario is not unlikely since upland reservoirs often supply irrigation water for lowland soils.

Modelling of ${ }^{90} \mathrm{Sr}$ and ${ }^{137} \mathrm{Cs}$ contents of foodstuffs in regions of the Dnieper cascade as a result of use of Dnieper water for irrigation was carried out by Perepelyatnikov and Prister (1992) and by Berkovski and coworkers (1996). In areas uncontaminated by direct Chernobyl fallout, the results showed that activity concentrations in irrigated agricultural produce increased over time after Chernobyl, although concentrations were relatively low (of order $1 \mathrm{~Bq} \cdot \mathrm{kg}^{-1}$ ), as illustrated in Fig. 3. Countermeasures to protect irrigation water are, in practice, the same as those to protect drinking water.

\section{Discussion}

Although freshwater pathways tend to give rise to relatively lower radioactive doses than terrestrial, certain elements of freshwater systems are potentially radiologically important. In the short term (timescale weeks) after an accident, surface drinking water supplies are potentially sensitive to high concentrations of radionuclides. It is noted that public concern over drinking water supplies is likely to be high. In general, over longer timescales (months to years after an accident), activity concentrations in drinking waters decline significantly. In the medium to long term (months to years), freshwater fish may have relatively high activity concentrations as a result of bioaccumulation of radiocaesium and to a lesser extent, radiostrontium.

It is impossible to make absolute recommendations of which countermeasures should be used in the event of radioactive contamination of freshwaters. We can, however, suggest which measures are likely to be most useful to decision makers, in the light of the critical review we have carried out. All of the measures we have outlined are discussed below.

Measures to reduce doses at the water supply and treatment stage.

Reduction of doses resulting from consumption of contaminated drinking water is most effective at the water supply and treatment stage. Measures to control water supply such as temporary bans, changes and blending of supplies, switching of reservoir abstraction to deeper waters, are simple, easily understood by the public, and effective. Intervention at the water treatment stage may also be effective (for example, filtering through activated charcoal, and zeolite). Since the radionuclide concentrations in water change rapidly after fallout, the effectiveness of these measures is dependent on their rapid implementation. This requires a rapid assessment of which supplies are likely to be 
contaminated, and a water supply system which is flexible enough to allow rapid blending or switching of supplies. Emergency decision support models would need to be used in order to identify those surface waters which may have radionuclide activity concentrations which are above acceptable limits.

Measures to reduce direct and secondary contamination of surface waters.

Experience from the Chernobyl accident showed that countermeasures to reduce concentrations of radioactivity in surface waters were not, in general, justified on radiological grounds. Sediment traps were found to be ineffective in removing particulates after Chernobyl. Standard anti- soil erosion methods are a possible way of reducing radioactive runoff in particulate form. However, in the context of a widespread atmospheric fallout, these would require large scale changes to catchments. Measures to reduce runoff of radionuclides in particulate form are limited because in most cases the majority of ${ }^{131} \mathrm{I},{ }^{90} \mathrm{Sr}$, and ${ }^{137} \mathrm{Cs}$ is likely to be in dissolved not particulate form. In addition, it is the dissolved, not the particulate phase which is important in determining radionuclide concentrations in biota and drinking water.

Measures to reduce runoff of radionuclides in dissolved form have not been well tested. On a small scale, filtering water through reed beds may be possible, but is unlikely to be of use over large areas. Filtering stream and river water through zeolite containing traps was found to be ineffective after Chernobyl (Voitsekhovitch et al., 1997). Construction of dykes around the Pripyat flood plain was effective in reducing peak ${ }^{90} \mathrm{Sr}$ concentrations in the Dnieper reservoir system (Zhelesnyak, 1997). It is estimated that during the high flood in 1994 these dykes reduced ${ }^{90} \mathrm{Sr}$ runoff from the floodplain by approximately $3.7 \times$ $10^{12} \mathrm{~Bq}$. It is not clear, however, that this measure was justified on purely radiological grounds, though it is believed to have helped restore public confidence in the water supply.

The removal of radionuclides from reservoirs by addition of strongly sorbing particulates to the reservoir is unlikely to be effective since secondary contamination from the catchment requires regular repetition of the treatment. The difficulty and expense of adding sorbing particulates (such as zeolites) to a reservoir is likely to be prohibitive.

\section{Measures to reduce uptake by fish and aquatic foodstuffs}

Bans on consumption of freshwater fish were widely applied and have been effective in Scandanavia. In the FSU, restrictions have not always been adhered to. Fish provide an important source of nutrition for people in these areas. It is possible that the radiological risk of fish consumption is outweighed by the benefits of this (often free) food supply. If bans on consumption of freshwater fish are to be effective in these areas, they must be adequately policed, and be complemented with alternative sources (e.g. farmed fish). Use of potassium to reduce ${ }^{137} \mathrm{Cs}$ activity concentrations in fish appears promising. It is, however, expected only to be cost-effective in lakes of long water retention time (greater than a few months). In tests in Sweden, other measures such as lake liming and biomanipulation were not found to be successful. 
Fish preparation methods.

Measures to reduce radioactivity at the food preparation stage are relatively simple and direct, also having the beneficial psychological effect of giving the consumer some control over his or her intake of radionuclides. In many developed countries, however, consumers are unlikely to accept sale of "contaminated” produce, making bans on consumption and fishing more likely to be used in practice.

\section{Cost of remedial measures.}

Costs of remedial measures are difficult to quantify since they will vary according to local economic conditions, availability of equipment etc. An estimate of countermeasure costs was, however, made in the Swedish study of 41 lakes, giving an indication of relative costs of the different countermeasures in Western European economic conditions. In the 41 lakes, the total cost of the remedies was about 23 million SEK (ca. 2.5 million EURO). The most expensive remedy (calculated per unit of volume) was fullscale liming with dolomite, followed by intensive fishing. The least expensive remedies were lake liming and potash treatment. It should be added that the expensive remedies (wetland liming and full-scale liming) are expected to have several biological and chemical advantages over normal lake liming and consequently, in an evaluation that also considers the long-term ecological effects, they may, in fact, give the best economic return. It should also be mentioned that even if this project had not been carried out, the liming remedies would generally have been done within the normal provincial liming programme to minimise the effects of anthropogenic acidification.

\section{Public perception and information.}

The key to successful implementation of countermeasures is the provision of accurate information to the public. Countermeasures can be counter-productive in increasing the stress people feel in a situation of radioactive contamination. If not accompanied by adequate information, the application of countermeasures may make people overestimate the danger of their exposure to radiation. People may feel that if countermeasures are necessary, the potential exposure must be "dangerous", even when actual radiation doses present only a small risk. Conversely, countermeasures may also be implemented to allay people's fears of radioactivity. Thus, after Chernobyl, measures were implemented to reduce radioactivity in the Kiev Reservoir even though doses via this pathway to the people of Kiev were relatively low.

\section{Conclusions}

We have reviewed a large number of measures to reduce doses of radionuclides via the freshwater pathway. These range from simple and well tested measures (e.g. bans on drinking water consumption) to more complex measures such as lake liming or potassium addition. We emphasise that we have primarily considered the case of a widespread surface aerial contamination of catchments and surface waters. Effectiveness and viability of countermeasures may be different for the case of small scale contamination of, for example, a reactor cooling pond. We further emphasise that we 
have considered radiological dose reduction effectiveness as the primary criterion of countermeasure viability: as noted above, countermeasures may be implemented for other (unquantifiable) reasons such as public reassurance.

Measures to reduce activity concentrations in drinking water.

We believe that the most effective and viable measures to reduce radioactivity in drinking water are those which operate at the water treatment and distribution stage. Intervention measures to reduce concentrations of radioactivity in rivers and reservoirs are expected to be much less viable and efficient at reducing doses via the drinking water pathway for two primary reasons:

(1) It is generally only possible to apply intervention measures to reduce concentrations of radioactivity in rivers and reservoirs in the medium term (months) after an accident since they require significant engineering works. Radioactivity concentrations in drinking water tend largely to be a short term problem - activity concentrations in water generally decline rapidly during the first few weeks after fallout. Thus intervention needs to be rapid and therefore based on accurate monitoring data and modelling;

(2) Intervention to reduce radioactivity concentrations in rivers and reservoirs necessarily requires manipulation of much larger volumes of water than intervention at the water treatment and supply stage.

Measures to reduce doses via consumption of freshwater biota.

We believe that direct measures to reduce uptake of radioactivity by fish, and food preparation measures are most likely to be viable and effective at reducing doses via consumption of fish and aquatic biota. De-boning fish contaminated by strontium is probably the most effective food preparation measure, but salting and freezing can also reduce radiocaesium concentrations. Bans on consumption of freshwater fish can be effective, but there are few viable measures to reduce radioactivity in fish prior to the preparation stage. Lake liming and biomanipulation were ineffective for radiocaesium, though addition of potassium to lakewaters appears promising in some lakes. Lake liming may be effective in reducing radiostrontium in fish, though this has not, to our knowledge, been tested. 


\section{References}

Balonov, M.I. \& Travnikova, I.G.(1990) The role of agriculture and natural ecosystems in forming the internal irradiation of citizens from the contaminated zone. In: Proc. First International Working Group on Severe Accidents and their Consequences (pp. 153160). Moscow: Nauka.

Berkovski, V., Voitsekhovitch, O.A., Nasvit, O., Zheleznyak, M. \& Sansone, U. (1996) Exposures from aquatic pathways. In The radiological consequences of the Chernobyl accident (pp 283-294). EUR 16544 EN, Luxembourg: European Commission.

Blaylock, B.G. (1982) Radionuclide data bases available for bioaccumulation factors for freshwater biota. Nuclear Safety, 23, 427-438.

Brittain, J.E., Storruste, A. \& Larsen, E. (1991) Radiocaesium in Brown Trout (Salmo trutta) from a subalpine lake ecosystem after the Chernobyl reactor accident. Journal of Environmental Radioactivity, 14, 181-191.

Bugai, D.A., Waters, R.D., Dzhepo, S.P.\& Skal'skij, A.S. (1996) Risks from radionuclide migration to groundwater in the Chernobyl 30-km zone. Health Physics, 71, 9-18.

Camplin, W.C., Leonard, D.R.P., Tipple, J.R. \& Duckett, L. (1989) Radioactivity in freshwater systems in Cumbria (UK) following the Chernobyl accident. MAFF Fisheries Research Data Report No. 18, Lowestoft, Ministry of Agriculture Fisheries and Food.

Coughtrey, P.J. \& Thorne, M.C. (1983) Radionuclide distribution and transport in terrestrial and aquatic ecosystems, Volume 1. Rotterdam: A.A. Balkema, 496p.

Elliott, J.M., Hilton, J., Rigg, E., Tullett, P.A., Swift, D.J. \& Leonard, D.R.P. (1992) Sources of variation in post-Chernobyl radiocaesium in fish from two Cumbrian lakes (North-West England). Journal of Applied Ecology, 29, 108-119.

Fleishman, D.G. (1973) Radioecology of marine plants and animals. In V.M. Klechkovskii, G.G. Polikarpov, R.M. Aleksakhin, Radioecology (pp 347-370). New York: John Wiley \& Sons.

Fleishman, D.G., Nikiforov, V.A., Saulus, A.A. \& Komov, V.T. (1994) ${ }^{137}$ Cs in fish of some lakes and rivers of the Bryansk region and North-West Russia in 1990-1992. Journal of Environmental Radioactivity, 24, 145-158.

Goossens, R., Delville, A., Genot, J., Halleux, R. \& Masschelein, W.J. (1989). Removal of the typical isotopes of the Chernobyl fall-out by conventional water treatment. Water Research, 23, 693-697.

Hadderingh, R.H., van Aerssen, G.H.F.M, Ryabov, I.N., Koulikov, A.O. \& Belova, N. (1997). Contamination of fish with ${ }^{137} \mathrm{Cs}$ in Kiev Reservoir and old river bed of Pripyat near Chernobyl. In G. Desmet, R. Blust, R.N.J. Comans, J.A. Fernandez, J. Hilton. \& A. 
de Bettencourt, Freshwater and estuarine radioecology, (pp. 339-351). Amsterdam: Elsevier.

Håkanson, L. (1999). Water pollution - methods and criteria to rank, model and remediate chemical threats to aquatic ecosystems. Leiden: Backhuys Publishers, 299 p.

Håkanson, L. \& Andersson, T. (1992) Remedial measures against radioactive Caesium in Swedish lake fish after Chernobyl. Aquatic Sciences, 54, 141-164.

Håkanson, L. \& Peters, R.H. (1995). Predictive limnology - methods for predictive modelling. Amsterdam, SPB Academic Publishers, 464 p.

Konoplev, A.V., Comans, R.N.J., Hilton, J., Madruga, M.J. Bulgakov, A.A, Voitsekhovitch, O.V., Sansone, U., Smith, J.T. \& Kudelsky, A.V. (1996) Physicochemical and hydraulic mechanisms of radionuclide mobilization in aquatic systems. In The radiological consequences of the Chernobyl accident (pp 121-135). Report EUR 16544 EN, Luxembourg, European Commission.

Kryshev I.I. (1995) Radioactive contamination of aquatic ecosystems following the Chernobyl accident. Journal of Environmental Radioactivity, 27, 207-219.

Kryshev, I.I. \& Ryabov, I.N. (1990) About the efficiency of trophic levels in the accumulation of Cs-137 in fish of the Chernobyl NPP cooling pond. In . I.N. Ryabov \& I.A. Ryabtsev Biological and radioecological aspects of the consequences of the Chernobyl Accident (pp. 116-121). Moscow: USSR Academy of Sciences.

Los, I.P., Segeda, I.I., Shepelevitch, K.I \& Voitsekhovitch, O.V. (1998) Assessment of radiation risks and reasonability for justification of the water remedial countermeasure (Radiological and social-economical criteria for decision making). In O.V. Voitsekhovitch, Radioecology of water bodies of the Chernobyl affected areas Vol. 2 (pp 136-168) Kiev: Chernobyl Inter-inform (in Russian).

Morgan, R.P.C. (1986) Soil erosion and conservation. Harlow: Longman 298 p.

NRPB (1996) Generalised derived limits for radioisotopes of $\mathrm{Sr}, \mathrm{Ru}, \mathrm{I}, \mathrm{Cs}, \mathrm{Pu}, \mathrm{Am}, \mathrm{Cm}$. Documents of the NRPB Vol. 7 No. 1, London: NRPB.

Perepelyatnikov G.P. \& Prister B.S. (1992) Migration of the Chernobyl radionuclides in fields irrigated by Dnieper water. In Problems of agricultural radiology, Volume 2, Ukraine: Institute of Agricultural Radiology.

Ryabov, I.N. (1992) Analysis of countermeasures to prevent intake of radionuclides via consumption of fish from the region affected by the Chernobyl accident. Proc. Int. Seminar on Intervention Levels and Countermeasures for Nuclear Accidents (pp. 379390). EUR 14469, Luxembourg: European Commission.

Sansone, U. \& Voitsekhovitch. O.V. (1996) Modelling and study of the mechanisms of the transfer of radionuclides from the terrestrial ecosystem to and in water bodies around Chernobyl. EUR 16529 EN, Luxembourg: European Commission. 
Schwab, G.O., Frevert, R.K., Edminster, T.W. \& Barnes, K.K. (1966) Soil and water conservation engineering. New York: Wiley.

Smith, J.T., Kudelsky, A.V., Ryabov, I.N., Hadderingh, R.H., van der Perk, M. \& Voitsekhovitch, O.V. (1999a) Chernobyl radionuclides $\left({ }^{131} \mathrm{I},{ }^{90} \mathrm{Sr},{ }^{137} \mathrm{Cs}\right)$ in surface waters of Belarus, Russia and Ukraine: an overview and model-based analysis. Verhandlungen Internationalis Vereinigung Limnologie, in press.

Smith, J.T., Comans, R.N.J. \& Elder, D.G. (1999b) Radiocaesium removal from European lakes and reservoirs: key processes determined from 16 Chernobyl contaminated lakes. Water Research, 33, 3762-3774.

Smith, J.T., Comans, R.N.J., Beresford, N.A., Wright, S.M., Howard, B.J., Camplin, W.C. (2000a) Chernobyl's legacy in food and water. Nature, 405, p141.

Smith, J.T., Kudelsky, A.V., Ryabov, I.N. \& Hadderingh, R.H. (2000b) Radiocaesium concentration factors of Chernobyl-contaminated fish: a study of the influence of potassium and "blind" testing of a previously developed model. Journal of Environmental Radioactivity, 48, 359-369.

Smith, J.T., Kudelsky, A.V., Ryabov, I.N. \& Hadderingh R.H. (2000c) Aquatic countermeasure against radiocaesium uptake by the ecosystem (AQUACURE) final report. Brussels: European Commission.

Stone, D., Smith, J.T., Jackson, D. \& Ibbotson, A.T. (1997) Scoping study on the relative importance of freshwater dose pathways following a major nuclear accident. Whitehaven: Westlakes Research Institute.

Strand, P., Howard, B. \& Averin, V. (Eds.) (1996) Transfer of radionuclides to animals, their comparative importance under different agricultural ecosystems, and appropriate countermeasures. EUR 16539 EN. Luxembourg: European Commission.

Tsarik, N. (1993) Supplying water and treating sewage in Kiev after the Chernobyl accident. Journal of the American Water Works Association, 85, 42-45.

Vakulovsky S.M. \& Voitsekhovitch, O. (1990). Radioactive contamination of water bodies in the area affected by releases from the Chernobyl Nuclear Power Plant accident Proceedings of the International Symposium, Environmental contamination following a major nuclear accident. IAEA, Vienna (pp.231-246).

Vakulovsky, S.M., Nikitin, A.I., Chumichev, V.B., Katrich, I. Yu., Voitsekhovitch, O.A., Medinets, V.I., Pisarev, V.V., Bovkum, L.A. \& Khersonsky, E.S. (1994) Caesium-137 and Strontium-90 contamination of water bodies in the areas affected by releases from the Chernobyl Nuclear Power Plant accident: an overview. Journal of Environmental Radioactivity, 23, 103-122.

Voigt, G., Eged, K., Hilton, J., Howard, B.J., Kis, Z., Nisbet, A.F., Oughton, D.H., Rafferty, B., Salt, C.A., Smith, J.T., and Vandenhove, H. (2000). Countermeasures: Radioecological and Social Impacts. A wider perspective on 
the selection of countermeasures. Report of the IUR, in press.

Voitsekhovitch, O.V, Kanivets, V.V. \& Shereshevsky A.I. (1988) The effectiveness of bottom sediment traps created to capture contaminated matter transported by suspended particles. Proceedings of the Ukrainian Hydrometeorological Institute, 228, 60-68 ( in Russian).

Voitsekhovitch, O.V., Borsilov, V.A. \& Konoplev, A.V. (1991) Hydrological Aspects of Radionuclides migration in water bodies following the Chernobyl Accident. Proceedings of the Seminar Comparative Assessment of Radionuclides released during three Major Nuclear Accidents: Kyshtym, Windscale and Chernobyl, Brussels, CEC (pp. 527-548).

Voitsekhovitch, O.V., Nasvit, O., Los’y, Y. \& Berkovski, V. (1997) Present thoughts on aquatic countermeasures applied to regions of the Dnieper river catchment contaminated by the 1986 Chernobyl accident. In G. Desmet, R. Blust, R.N.J. Comans, J.A. Fernandez, J. Hilton. \& A. de Bettencourt, Freshwater and estuarine radioecology, (pp. 75-86). Amsterdam: Elsevier.

Voitsekhovitch, O.V. (1998) Water quality management of the radioactive contaminated waters (Strategy and Technology). In O.V. Voitsekhovitch, Radioecology of the water bodies at the areas affected as a result of Chernobyl accident (pp 169-217). Kiev: Chernobyl Inter-inform (in Russian).

Wallström, A. \& Hakanson, L. (1991). A household method to reduce Cs-137 in meat. Stockholm: Swedish Health and Food Institute (in Swedish).

Zheleznyak M., Shepeleva, V., Sizonenko, V. \& Mezhueva, I. (1997) Simulation of countermeasures to diminish radionuclide fluxes from the Chernobyl zone via aquatic pathways. Radiation Protection Dosimetry, 73, 181-186.

Zibold, G., Förschner, A., Drissner, J., Klemt, E., Miller, R., Walser, M. (1998). Time-dependency of the caesium-137 concentration factor in pike from lake Vorsee. Proceedings of the UIR Topical Meeting, Mol, Belgium. 
Table 1. Radionuclide levels in the R. Pripyat at Chernobyl, 1 May 1986 (Kryshev, 1995). For some (radiologically important) radionuclides, annual GDL's for drinking water (NRPB, 1996) in the UK are shown for comparison. These are calculated as the activity concentration of a given radionuclide which would result in a $1 \mathrm{mSv}$ dose over a period of one year. Although initial activity concentrations of radionuclides in Pripyat water exceeded GDL's, concentrations rapidly dropped to significantly below GDL's after a few weeks following fallout.

\begin{tabular}{llll}
\hline Radionuclide & $\begin{array}{l}\text { Initial content in } \\
\text { Pripyat water, Bq. } l^{-1}\end{array}$ & $\begin{array}{l}\text { UK GDL for } \\
\text { drinking water Bq. } l^{-1}\end{array}$ & Half-life of isotope \\
\hline Cs-137 & 250 & 100 & $30.2 \mathrm{y}$ \\
Cs-134 & 130 & 90 & $2 \mathrm{y}$ \\
I-131 & 2100 & 20 & $8.1 \mathrm{~d}$ \\
Sr-90 & 30 & 50 & $28 \mathrm{y}$ \\
Ba-140 & 1400 & - & $12.8 \mathrm{~d}$ \\
Mo-99 & 670 & - & $3 \mathrm{~d}$ \\
Ru-103 & 550 & 800 & $40 \mathrm{~d}$ \\
Ru-106 & $177^{*}$ & 80 & $365 \mathrm{~d}$ \\
Ce-144 & 380 & - & $284 \mathrm{~d}$ \\
Ce-141 & 400 & - & $33 \mathrm{~d}$ \\
Zr-95 & 400 & - & $65 \mathrm{~d}$ \\
Nb-95 & 420 & - & $35 \mathrm{~d}$ \\
Pu-241 & $33^{* *}$ & 400 & $13 \mathrm{y}$ \\
Pu-239,240 & 0.4 & 7 & $2.4 \mathrm{x} 10^{4} \mathrm{y}$ \\
& & & $6.6 \mathrm{x} 10^{3} \mathrm{y}$ \\
\hline
\end{tabular}

* From Ru-103 measurement and Ru-103/Ru-106 ratio ( 3) for Chernobyl fallout. ** From Pu-239,240 measurement and Pu-241/Pu-239,240 ratio ( 82) for Chernobyl fallout. 
Table 2. Temporary allowable levels of radionuclides in drinking water in the Ukraine at different times after Chernobyl (Los, Segeda, Shepelevitch \& Voitsekhovitch, 1998). The dates refer to the time at which each new regulation was implemented.

\begin{tabular}{lcccc}
\hline Radionuclide & 6 May 86 & 30 May 86 & 15 Dec 87 & 22 Jan 91 \\
\hline${ }^{131} \mathrm{I}$ & 3700 & & & \\
$\left(\mathrm{~Bq} . \mathrm{l}^{-1}\right)$ & & & & \\
Total beta & & 370 & & \\
$\left(\mathrm{~Bq} . \mathrm{l}^{-1}\right)$ & & & 18.5 & 18.5 \\
${ }^{137} \mathrm{Cs}+{ }^{134} \mathrm{Cs}$ & & & \\
$\left(\mathrm{Bq} . \mathrm{I}^{-1}\right)$ & & & 3.7 \\
${ }^{90} \mathrm{Sr}$ & & & \\
$\left(\mathrm{Bq} . \mathrm{l}^{-1}\right)$ & & & \\
\hline
\end{tabular}


Table 3. Mass of material required to decrease removal time of radiocaesium by a factor of 2 in three lakes of different sizes.

\begin{tabular}{|c|c|c|c|c|c|}
\hline Lake & $\begin{array}{c}\text { Volume } \\
\mathrm{m}^{3}\end{array}$ & $\begin{array}{c}\text { Mean annual } \\
\text { suspended } \\
\text { solids conc. } \\
{\text { mg. }{ }^{-1}}^{\text {. }}\end{array}$ & $\begin{array}{c}{ }^{137} \mathrm{Cs} \\
\text { removal } \\
\text { time (days) }\end{array}$ & $\begin{array}{c}\text { Additional suspended } \\
\text { solids conc. required } \\
\text { to decrease removal } \\
\text { time by a factor of } 2 \text {, } \\
\text { mg. } l^{-1}\end{array}$ & $\begin{array}{c}\text { Tonnes of } \\
\text { solids } \\
\text { added }\end{array}$ \\
\hline $\begin{array}{l}\text { Blelham } \\
\text { Tarn }\end{array}$ & $7 \times 10^{5}$ & 1.1 & 22 & 7 & 4.2 \\
\hline $\begin{array}{l}\text { Windermere } \\
\text { North Basin }\end{array}$ & $2 \times 10^{8}$ & 1.1 & 126 & 3.5 & 600 \\
\hline $\begin{array}{l}\text { Lake } \\
\text { Constance }\end{array}$ & $5 \times 10^{10}$ & 1.0 & 167 & 1.3 & 66,000 \\
\hline
\end{tabular}






Figure 1. Freshwater dose pathway indicating potential intervention measures. Dashed lines indicate pathways of lower potential importance. 
Figure 2. Predicted effect of different particulate sorbed fractions $\left(f_{p}\right)$ of radiocaesium on its residence time in lakes.

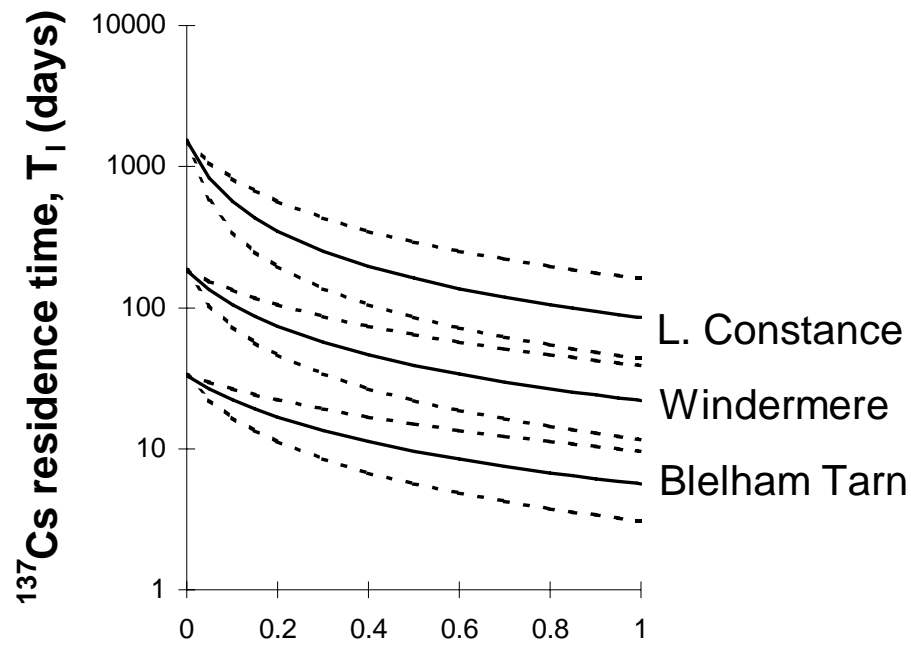

Particulate sorbed fraction, $\mathbf{f}_{p}$

Figure 3. Predicted increase in ${ }^{90} \mathrm{Sr}$ concentration in rice as a result of irrigation with water from the Dnieper river-reservoir system (from Perepelyatnikov and Prister 1992).

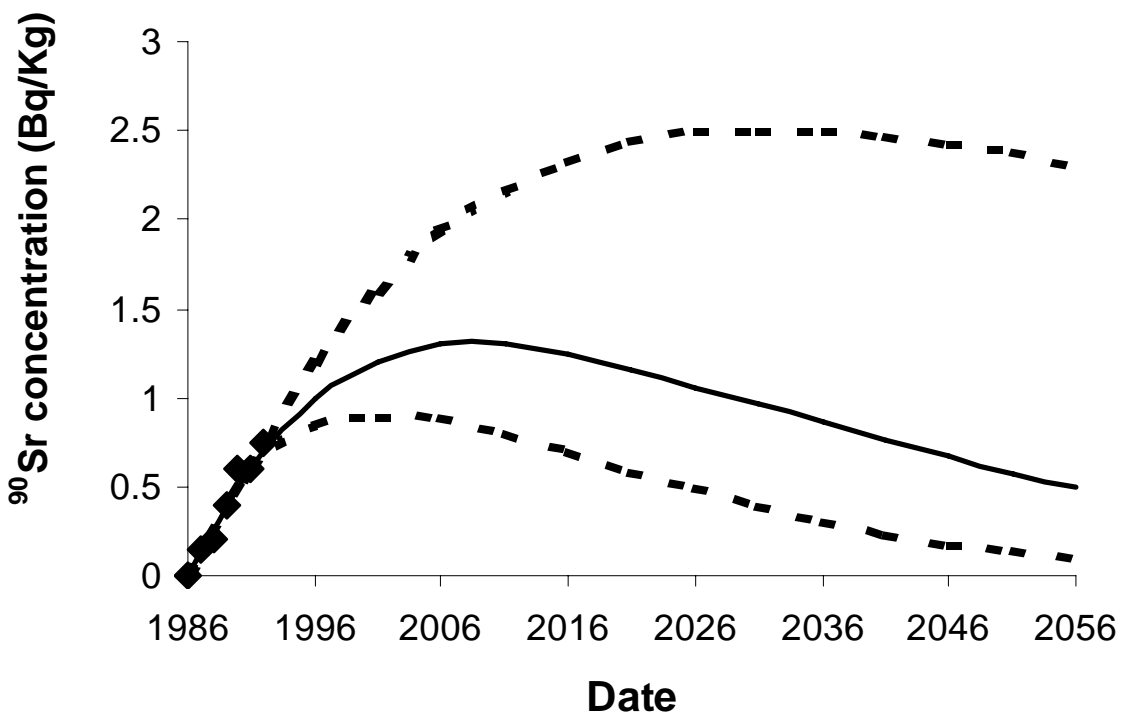

- Predicted concentration

- Observed concentration

- - Range for $50 \%$ deviation of clearance constant 